\title{
Contraction of Wildlife Dispersal Area and Displacement by Human Activities in Kimana Group Ranch Near Amboseli National Park, Kenya
}

\author{
Moses Makonjio Okello*
}

The School for Field Studies, Center for Wildlife Management Studies, Kenya. P. O. Box 27743-00506, Nairobi, Kenya

\begin{abstract}
Kimana Group Ranch area is a critical area for Amboseli, Chyulu, Tsavo West national parks, and community sanctuaries in the Tsavo - Amboseli Ecosystem. However, growing human populations and associated activities are causing range contraction and wildlife displacement in this dispersal area. This study investigated the contraction of wildlife dispersal area through field mapping and spatial analysis. Human activities displaced wildlife from $140.01 \mathrm{~km}^{2}$ $(55.74 \%)$ of KGR, leaving only about $44 \%$ of the land for wildlife. The actual area occupied by these activities was 57.83 $\mathrm{km}^{2}$ (23\% of KGR). Wildlife kept $0.23 \pm 0.04 \mathrm{~km}$ from Maasai homes, $0.18 \pm 0.02 \mathrm{~km}$ from roads, $0.07 \pm 0.04 \mathrm{~km}$ from electric fences, and $0.21 \pm 0.02 \mathrm{~km}$ from livestock. No wildlife was seen close to agricultural areas, which covered 0.89 $\mathrm{km}^{2}, 0.27 \%$. Kimana and Namelok electric fences covered $52.98 \mathrm{~km}^{2}(21.10 \%)$, but displaced wildlife from $69.29 \mathrm{~km}^{2}$ (27.61\%). Although Maasai homes covered only $0.24 \mathrm{~km}^{2}(1.09 \%)$, they displaced wildlife from $28.11 \mathrm{~km}^{2}(11.19 \%)$. Spatially, clusters of human activities were cutting off Amboseli and KCWS, forcing the wildlife to find alternative routes with Tsavo / Chyulu. Therefore, Kimana is diminishing as wildlife dispersal area and this will affect the viability of protected areas.
\end{abstract}

Keywords: Corridors, Kenya, Kimana Group Ranch, Tsavo-Amboseli ecosystem, Wildlife dispersal areas, Wildlife displacement.

\section{INTRODUCTION}

Insularization of protected areas and habitat fragmentation lead to the extinction of species, directly reducing biodiversity [1-3]. Isolation reduces the effective size of an area by limiting movement of species and causing faunal relaxation [4]. If the protected areas have no dispersal areas, genetic drift and inbreeding may occur, leading to population instability, loss of ecological integrity and possibly local extinction [5]. Isolation can be caused by various factors such as roads or fences, areas of agriculture or dense human population [6].

The threat of biodiversity loss is an eminent one for East African protected areas as they become increasingly insularized by the growing human population in surrounding areas outside protected areas, human activities such as settlement, agricultural cultivation, and active elimination of wildlife on land adjacent to parks [6, 7]. In the Amboseli area, attributes associated with rapid population growth and land use changes threaten to completely isolate protected areas from each other [7]. It is likely that protected areas will lose a significant proportion of their large mammal fauna if they become completely insularized [10].

But the frequency of human wildlife conflict can be inversely related to human density and land use changes on lands adjacent to protected areas [8]. Also human population density has been a major indicator and predictor of large mammal local extinctions. An increase in human population

*Address correspondence to this author at the School for Field Studies, Center for Wildlife Management Studies, Kenya. P. O. Box 27743-00506, Nairobi, Kenya; E-mail: mokello@fieldstudies.org; moses_okello@yahoo.com and human associated activities decreases wildlife population space and dispersal and leads to an increase in human wildlife conflicts [9]. These human-wildlife conflicts create frustration and animosity towards wildlife and may result in retaliation killings $[7,10]$.

This study aimed to establish the contraction of Kimana Group Ranch (KGR) as a wildlife dispersal space. The specific objectives were to:

i) Determine what human structures and activities reduce dispersal area in KGR.

ii) Determine spatial location and distribution of these human structures and activities and implications for wildlife dispersal.

iii) Determine displacement effects of these human structures and activities, including livestock presence on wild mammals

iv) Explore potential mitigation measures and the way forward for conservation in this critical dispersal area.

\section{THE STUDY AREA}

Kimana Group Ranch (KGR) is located in the Tsavo Amboseli Ecosystem (Fig. 1). KGR is $251 \mathrm{~km}^{2}$ in area. The group ranch supports free ranging wildlife. Therefore, Kimana Community Wildlife Sanctuary (KCWS) was established by the community in 1996 [11]. It provides a dry season concentration area just like Amboseli Park [12].

Amboseli National Park was designated as a national game reserve in 1948 with an area of $3260 \mathrm{~km} 2$, and managed by local Kajiado County Council. However, the mismanagement of the park (loss of revenue and overgrazing by Maasai cattle) led the government to designate a small 


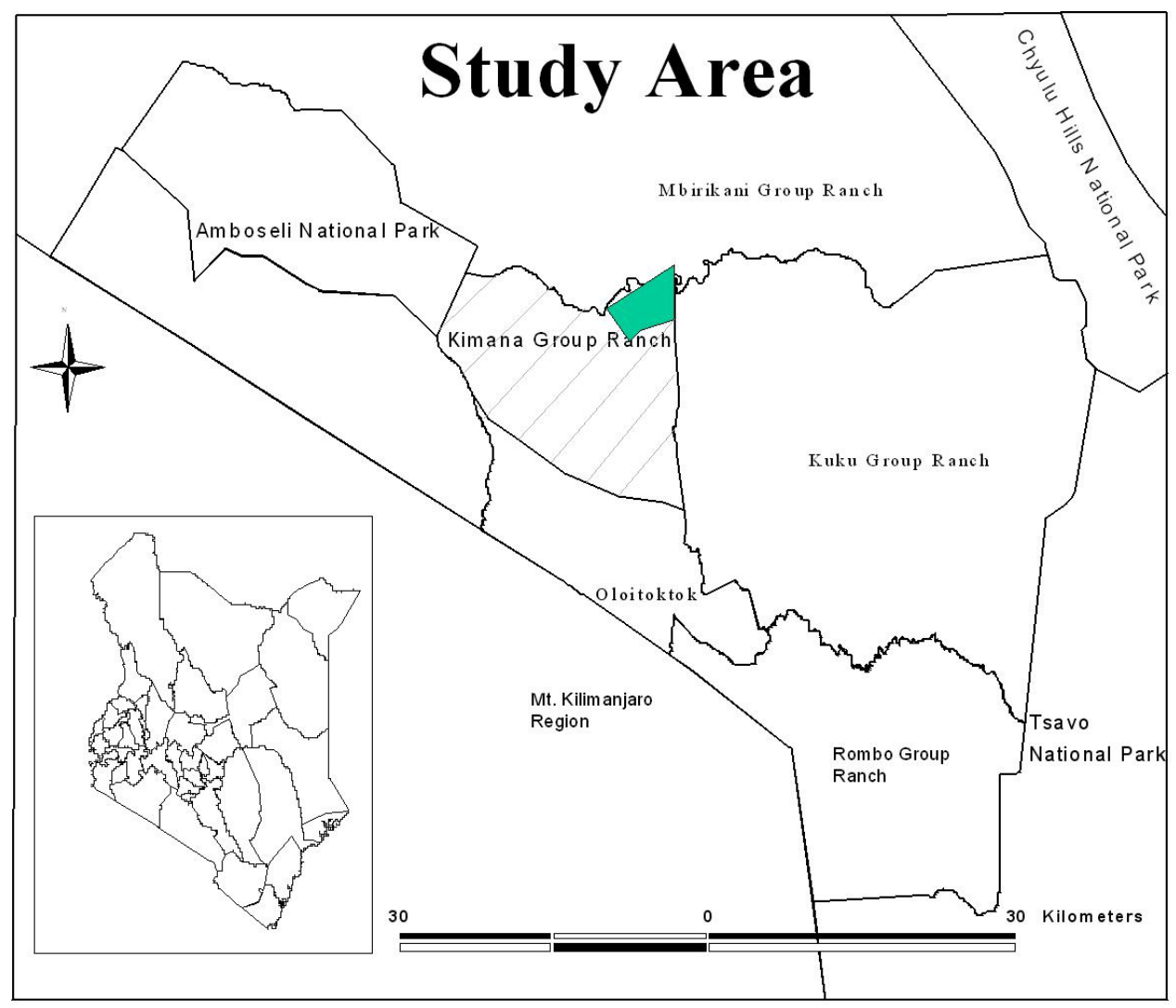

Fig. (1). The six group ranches between Amboseli National Park and Tsavo / Chyulu Parks form critical wildife dispersal areas and migration routes between protected areas. Chyulu / Tsavo West Natonal Parks are to the east of Mbirikani and Kuku Group Ranches.

area of $392 \mathrm{~km}^{2}$ as a national park in 1974, and the rest of the area given to Maasai for settlement and pastoralism. This is the land comprised of the six group ranches and which is communally owned by the Maasai. Because Amboseli National Park is not fenced, Maasai communal lands around Amboseli are critical as mainly wet season dispersal area for Amboseli National Park. This land is not just a dispersal area for wildlife, but have resident wildlife herds which share water, space and pasture with Maasai cattle throughout the year [12].

Amboseli Area is a semi-arid and arid rangeland with a bimodal rainfall, as it occurs in the rain shadow of Mt. Kilimanjaro. Long rains occur from March to early June and the short rains occur in October and November. KGR receives $210 \mathrm{~mm}$ annually, with $30 \%$ received during the short rains and $45 \%$ in the long rains [13].

The Kimana rangeland has dense and open shrubland, bushland, and woodland habitats. The dominant vegetation in the riverine habitat is Acacia xanthophloea and the drier regions are dominated by Acacia tortillis and Acacia mellifera (Irigia, 1995). Soils are shallow but fertile volcanic, and are saline and alkaline. Only swamps and riverine areas are suitable for agriculture while the entire range is suitable for wildlife and pastoralism [14].

\section{METHODS AND MATERIALS}

Spatial location, area and wildlife displacement effects were assessed for Maasai homesteads (bomas), roads, markets, electric fences, public institutions, and agriculture.
Research was done in two wet season (the first in November 2004 and the second in April 2005) when wildlife is dispersing in group ranches.

\section{Wildlife Sightings in Relation to Human Activities and Livestock}

All wild large mammals (larger than a Kirk's Dik-dik Madoqua kirkii, and all primates) in KGR outside electric fences and close to human structures / activities were mapped whenever they were sighted. Once wildlife was spotted, their exact location was recorded using Global Positioning Systems (GPS, Version III Plus, Germin Corporation, 1999). Further, the species, number of individuals in each group, and general habitat type (open grassland, Open woodland / shrubland, dense woodland / shrubland, and riverine) were noted. The distance to livestock and any human structure / activity nearby was recorded using a rangefinder $\left(\right.$ Bushnell $^{\circledR}$ Laser Rangefinder, Yardage Pro ${ }^{\mathrm{TM}} 400$, Bushnell Corporation USA ). This distance that wildlife kept away from human structures / activities was regarded as an index of the "displacement effect".

\section{Spatial Locations of Human Structures / Activities}

Maasai homesteads (bomas), public institutions, electric fences, market centers, Kimana Community Wildlife Sanctuary (KCWS) and agricultural fields were mapped using a GPS. To obtain the location and dimensions of human structure / activities, GPS points were taken at central and along the perimeter. Multiple GPS coordinates along the perimeter were taken always for larger structures / activities. 
For markets, all facilities (shops, social areas, and residential areas) associated with market were considered part of the market infrastructure. After mapping, areas close by were scanned by standard binocular to spot any large wild mammals (including primates) present and distance from human structures / activities.

\section{Road Network and Area Mapping}

To establish location and area of roads, GPS points were taken every one kilometer along main roads, and every half kilometer on minor or feeder roads, and at every curve of more than $30^{\circ}$. All roads in Kimana Group Ranch were mapped. The length of each road segment was determined with a vehicle odometer, while the width was recorded at every GPS point using tape measure or a rangefinder.

Every road segment was noted as main, minor or feeder roads. The name of the road from places being linked was given. The mean widths and total length was used to compute the area and road network. The entire road reserve was included in width determination. Further, along the roads during this work, surrounding areas were scanned for large wild mammals (including primates) present and distance from the road.

\section{Data Analysis}

The network and average area covered by all human structures / activities were calculated from measured parameters (radius, lengths and widths) using standard arithmetic techniques. All Global Positioning System (GPS) coordinates were entered into a Geographical Information System (GIS) Using ARC - View ${ }^{\circledR}$ software (Version 3.3, Environmental Systems Research Institute, Inc., 2000 for spatial analysis and generation of maps.

An average distance of each large mammal species to livestock and human activities / structures was determined. This distance was added on measured parameters (radius, length, widths) of human structures / activities to estimate the area of wildlife displacement for that activity / structure. The displacement area was first determined for each unit (such as a single boma, road type, fence) and then for total units of that activity / structure (such as total bomas, fences, agriculture etc).

\section{RESULTS}

\section{Area and Wildlife Displacement by Livestock and Human Structures / Activities}

All human structures and activities displaced wildlife (actual and displacement area) from a total area of 140.01 $\mathrm{km}^{2}(55.74 \%)$, leaving about $44 \%$ of KGR available for wildlife and livestock (Table 1). However, only $57.83 \mathrm{~km}^{2}$ (about 23\%) was actually taken by all human activities /structures. Public institutions covered a small actual area, but displaced wildlife from a total of $5.2 \mathrm{~km}^{2}(2.07 \%)$ with a

Table 1. Actual Area Occupied by Human Structures as well as Associated Wildlife Displacement Area in Kimana Group Ranch

\begin{tabular}{|c|c|c|c|c|c|}
\hline $\begin{array}{l}\text { Human Structures and Activities } \\
\text { in Kimana Group Ranch }\end{array}$ & $\begin{array}{l}\text { Perimeter } \\
(\mathbf{k m})\end{array}$ & $\begin{array}{l}\text { Area of KGR } \\
\text { Actually Taken } \\
\left(\mathbf{k m}^{2}\right)\end{array}$ & $\begin{array}{l}\text { Proportion } \\
(\%) \text { of Total } \\
\text { KGR Area }\end{array}$ & $\begin{array}{l}\text { Area of KGR Actually Taken } \\
\text { Inclusive of Wildlife } \\
\text { Displacement Area }\left(\mathrm{km}^{2}\right)\end{array}$ & $\begin{array}{l}\text { Proportion }(\%) \text { of } \\
\text { Total KGR Inclusive } \\
\text { of Wildlife } \\
\text { Displacement Area }\end{array}$ \\
\hline Amboseli Sopa Lodge & 3.02 & 0.11 & 0.04 & \multirow{7}{*}{$\begin{array}{l}5.2 \\
\text { (all institutions together) }\end{array}$} & \multirow{7}{*}{$\begin{array}{l}2.07 \\
\text { (All institutions } \\
\text { together) }\end{array}$} \\
\hline $\begin{array}{l}\text { SFS Center for Wildlife } \\
\text { Management Studies }\end{array}$ & 1.52 & 0.14 & 0.06 & & \\
\hline Kimana Secondary school & 1.67 & 0.14 & 0.06 & & \\
\hline $\begin{array}{l}\text { Commercial Cultural Manyattas } \\
\text { (three at Amboseli, Sopa Lodge } \\
\text { and KCWS) }\end{array}$ & 0.5 & 0.03 & 0.01 & & \\
\hline Churches & 6.21 & 0.19 & 0.08 & & \\
\hline Schools & 4.28 & 0.28 & 0.11 & & \\
\hline Government offices & 2.08 & 0.12 & 0.05 & & \\
\hline Bomas & - & 0.24 & 1.09 & 28.11 & 11.19 \\
\hline Agriculture & - & 0.69 & 0.27 & No wildlife sighted closer & - \\
\hline Other Institutions & 0.37 & 0.002 & 0.0006 & - & - \\
\hline Electric Fences & - & 52.98 & 21.10 & 69.29 & 27.61 \\
\hline $\begin{array}{l}\text { TOTAL of all human structures } \\
\text { and activities }\end{array}$ & - & $57.83^{1}$ & 23.02 & 140.01 & 55.74 \\
\hline $\begin{array}{l}\text { Kimana Community Wildlife } \\
\text { Sanctuary (KCWS) }\end{array}$ & 21.85 & 24.04 & 9.57 & - & - \\
\hline
\end{tabular}

${ }^{1}$ Adjustment to areas was done to eliminate double counting for structures and activities within electric fences. No wildlife was therefore seen in human activities enclosed within electric fences (markets, institutions). No wildlife was seen close to agriculture found outside electric fences. 
Table 2. Area of Roads and Electric Fences Including Wildlife Displacement Effect in Kimana Group Ranch

\begin{tabular}{|c|c|c|c|c|c|c|}
\hline $\begin{array}{l}\text { Type of Road (all were } \\
\text { Marrum Roads) }\end{array}$ & $\begin{array}{l}\text { Total } \\
\text { Length }(\mathbf{k m})\end{array}$ & $\begin{array}{l}\text { Average } \\
\text { Width }(\mathbf{k m})\end{array}$ & $\begin{array}{l}\text { Total Area } \\
\left(\mathbf{k m}^{2}\right)\end{array}$ & $\begin{array}{l}\text { Percentage (\%) } \\
\text { of Group Ranch }\end{array}$ & $\begin{array}{l}\text { Road Area and } \\
\text { Displacement }\left(\mathbf{k m}^{2}\right)\end{array}$ & $\begin{array}{l}\text { Percentage (\%) of Group } \\
\text { Ranch with Displacement }\end{array}$ \\
\hline Isinet - Kimana main road & 16.28 & 0.019 & 0.30 & 0.12 & 3.06 & 1.22 \\
\hline $\begin{array}{l}\text { Amboseli road (off main } \\
\text { Kimana - Oloitoktok road) }\end{array}$ & 21.60 & 0.008 & 0.18 & 0.07 & 3.84 & 1.53 \\
\hline Major roads & 113.58 & 0.008 & 0.94 & 0.37 & 20.20 & 8.04 \\
\hline Total & 219.20 & 0.010 & 1.69 & 0.47 & 38.22 & 13.79 \\
\hline The electric fence location & \multicolumn{2}{|l|}{ Perimeter $(\mathrm{km})$} & Area $\left(\mathrm{km}^{2}\right)$ & $\begin{array}{l}\text { Percentage }(\%) \text { of } \\
\text { KGR }\end{array}$ & $\begin{array}{l}\text { Displacement area } \\
\left(\mathrm{km}^{2}\right)\end{array}$ & $\begin{array}{l}\text { Displacement Percentage } \\
(\%) \text { of KGR }\end{array}$ \\
\hline Kimana & \multicolumn{2}{|l|}{34.51} & 42.39 & 16.88 & 53.07 & 21.12 \\
\hline
\end{tabular}

*Area and perimeter within Kimana Group Ranch. Total Namelok Fence was $18.11 \mathrm{~km}^{2}$ and total perimeter was $21.15 \mathrm{~km}$ as covers part of Mbirikani and Ololorashi group ranch.

$0.18 \pm 0.06 \mathrm{~km}$ of wildlife displacement distance (Table 3). Bomas also took a small total actual area $\left(0.24 \mathrm{~km}^{2}, 1.09 \%\right)$, but the area increased to $28.11 \mathrm{~km}^{2}(11.19 \%)$ for wildlife displacement, and a displacement distance of $0.23 \pm 0.04$ $\mathrm{km}$.

Kimana Community Wildlife Sanctuary had the largest area $\left(24.04 \mathrm{~km}^{2}, 9.57 \%\right)$ of community / public institutions within the group ranch (Table 1). Besides KCWS, only $34.89 \%$ of land available after wildlife displacement effects, but about $67.43 \%$ of KGR assuming no additional wildlife displacement.

Roads had a network of 219 kilometers (Table 2) and covered an actual area of $1.69 \mathrm{~km}^{2}(0.47 \%$ of KGR). But this area increased to a wildlife displacement area of 38.22 $\mathrm{km}^{2}(13.79 \%)$. Wildlife kept off roads an average distance of $0.18 \pm 0.02$ (Table 3), with the Maasai giraffe (Giraffa camelopardalis) keeping off further $(0.19 \pm 0.05 \mathrm{~km})$ but the African elephant (Loxodonta africana) the least $(0.17 \pm 0.05$ $\mathrm{km})$.

The electric fences covered the largest total actual area $\left(52.98 \mathrm{~km}^{2}, 21.09 \%\right)$ in KGR (Table 1). This area increased to a wildlife displacement area of $69.29 \mathrm{~km}^{2}(27.58 \%)$, with displacement distance of $0.07 \pm 0.04 \mathrm{~km}$ (Table 3). Kimana fence had an actual area of $42.39 \mathrm{~km}^{2}(16.88 \%)$ but a displacement area of $53.07 \mathrm{~km}^{2}(21.12 \%)$, while Namelok had an actual area of $10.59 \mathrm{~km}^{2}(4.22 \%)$ but a displacement area of $16.22 \mathrm{~km}^{2}(6.46 \%)$.

Markets covered only $0.58 \mathrm{~km}^{2}(0.23 \%)$, with the two largest markets: Kimana $\left(0.48 \mathrm{~km}^{2}, 0.19 \%\right)$ and Namelok $\left(0.06 \mathrm{~km}^{2}, 0.02 \%\right)$ being the main markets (Table 3). The majority of institutions and markets were inside Kimana and Namelok electric fences. Therefore, no wildlife was sighted closer to markets and most institutions. Similarly, agriculture was mainly located inside the electric fences, with a very small proportion outside the fence $\left(0.89 \mathrm{~km}^{2}(0.27 \%)\right.$. No wildlife was sighted in close proximity to these agricultural areas.
The displacement of wildlife by livestock was $0.21 \pm$ $0.02 \mathrm{~km}$. Shoats (sheep and goats together) displaced wildlife the most $(0.20 \pm 0.03 \mathrm{~km})$. Cattle displaced wildlife next $(0.18 \pm 0.03 \mathrm{~km})$, but donkeys the least $(0.05 \pm 0.03$ $\mathrm{km})$.

\section{Spatial Relationships of Human Structures and Activities and Wildlife}

Most human structures /activities clustered mostly inside and around electric fences, and associated with roads, rivers and market centers (Fig. 2). However, wildlife was distributed all across the group ranch, but had higher numbers closer to protected areas, water sources and areas without or with little human activities / structures (Fig. 2).

Spatially, human structures and activities seemed to occur in clusters and were blocking the south western wildlife entry into KCWS. Electric fences run longitudinally in a north - south direction, thereby preventing most wildlife access to Kimana Sanctuary (Fig. 3). There were only five kilometers between the two fences at the entry to KCWS. The southern boundary of KCWS was blocked almost completely by Kimana fence, and about half of the western boundary by Namelok fence. The remaining corridor between Namelok fence and boma clusters was $1.82 \mathrm{~km}$, and only 111.75 meters between boma clusters and Kimana fence near KCWS (Fig. 2).

\section{DISCUSSIONS AND CONCLUSIONS}

The threat to wildlife dispersal areas and corridors in Kimana is both spatial and actual area taken by human activities. Over half of KGR been taken over by human structures, and wildlife greatly displaced by especially bomas, roads, electric fences and agriculture. The fact that we could not see any wildlife close to agricultural areas is evidence for agriculture's high wildlife displacement potential [15]. People persecute wildlife to push them away from farms to reduce crop raiding. Further, the people who farm spend lots of energy guarding their crops day and night using noise, fire and other crude weapons which further scare, intimidate and displace wildlife. Many farm attendants 
Table 3. Average Distance $(\mathrm{km})$ of Wildlife Displacement from Human and Livestock Presence in Kimana Group Ranch

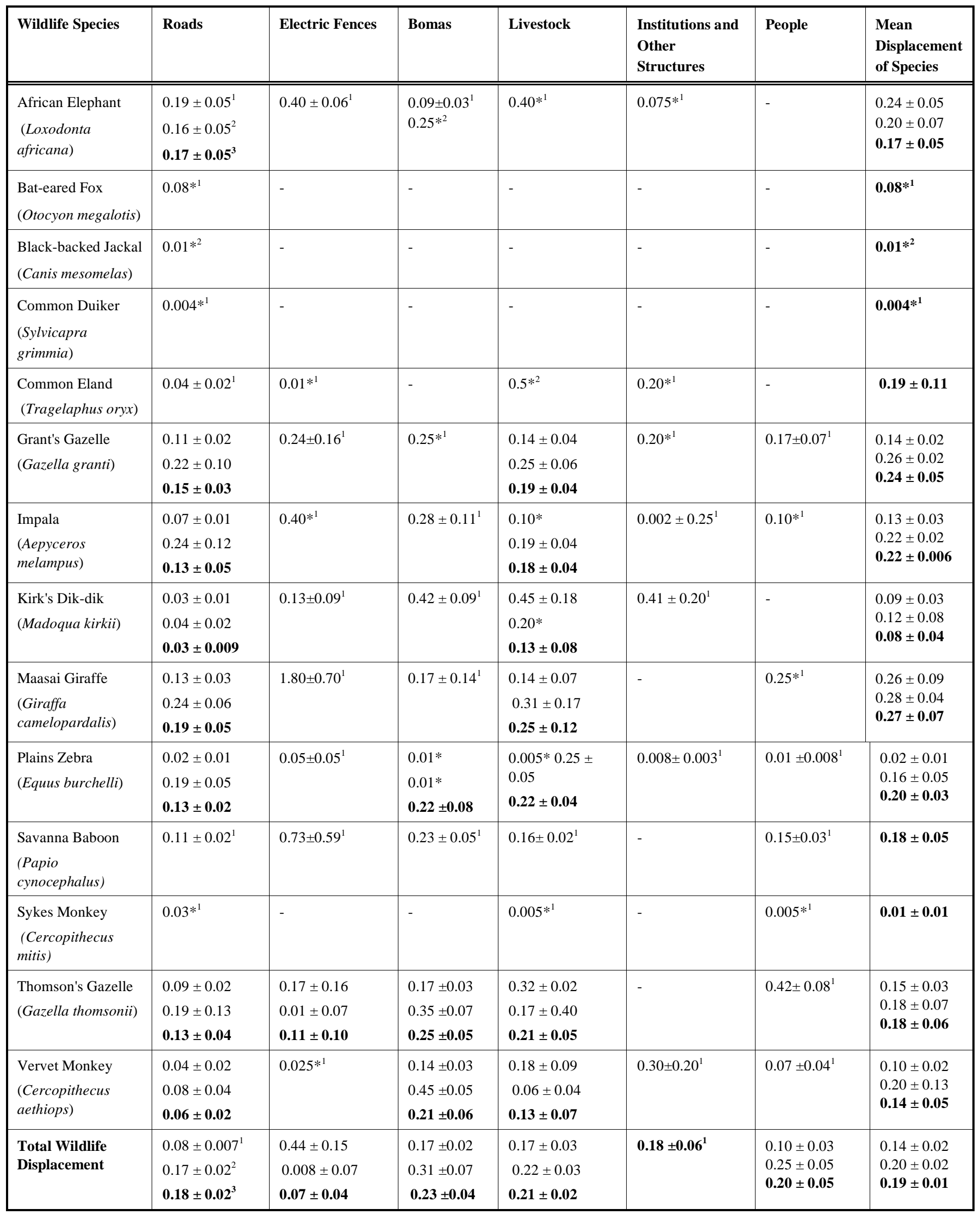

*Indicates that there was only one sample for that category.

${ }^{1}$ November $2004,{ }^{2}$ April $2005,{ }^{3}$ Average (in bold), respectively. 


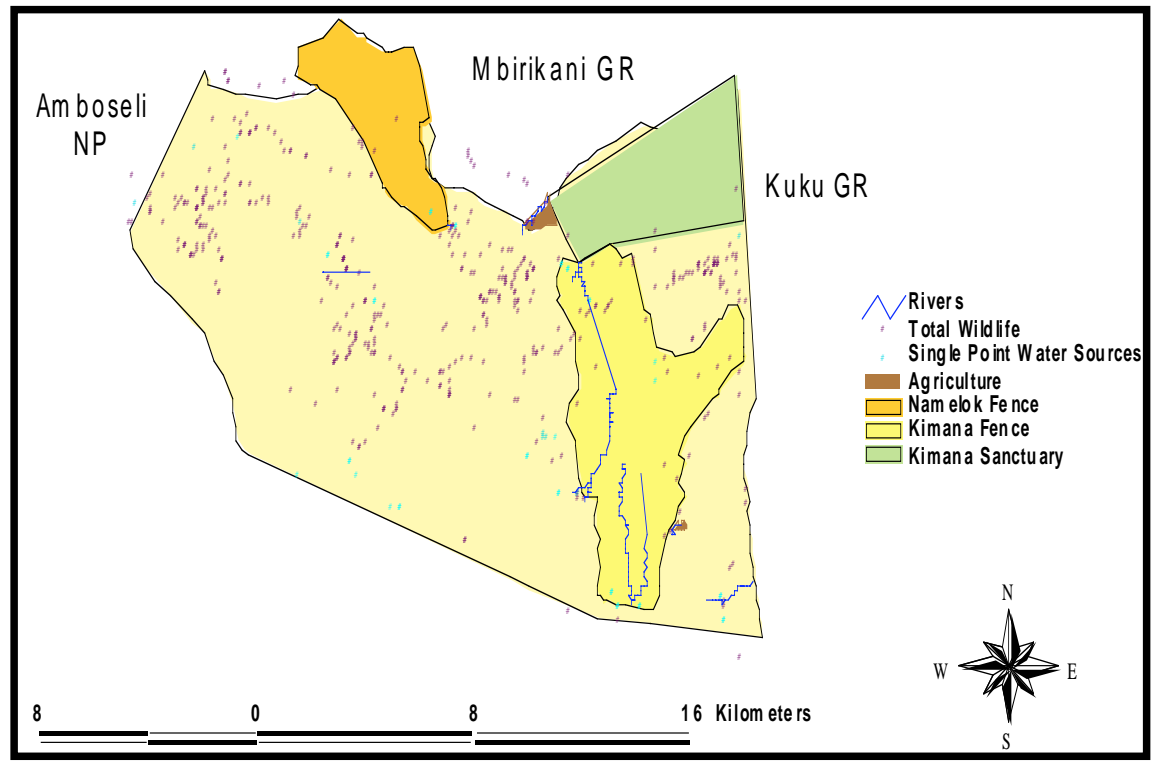

Fig. (2). Spatial distribution of wildlife in relation to water sources and agricultural clusters in KGR.

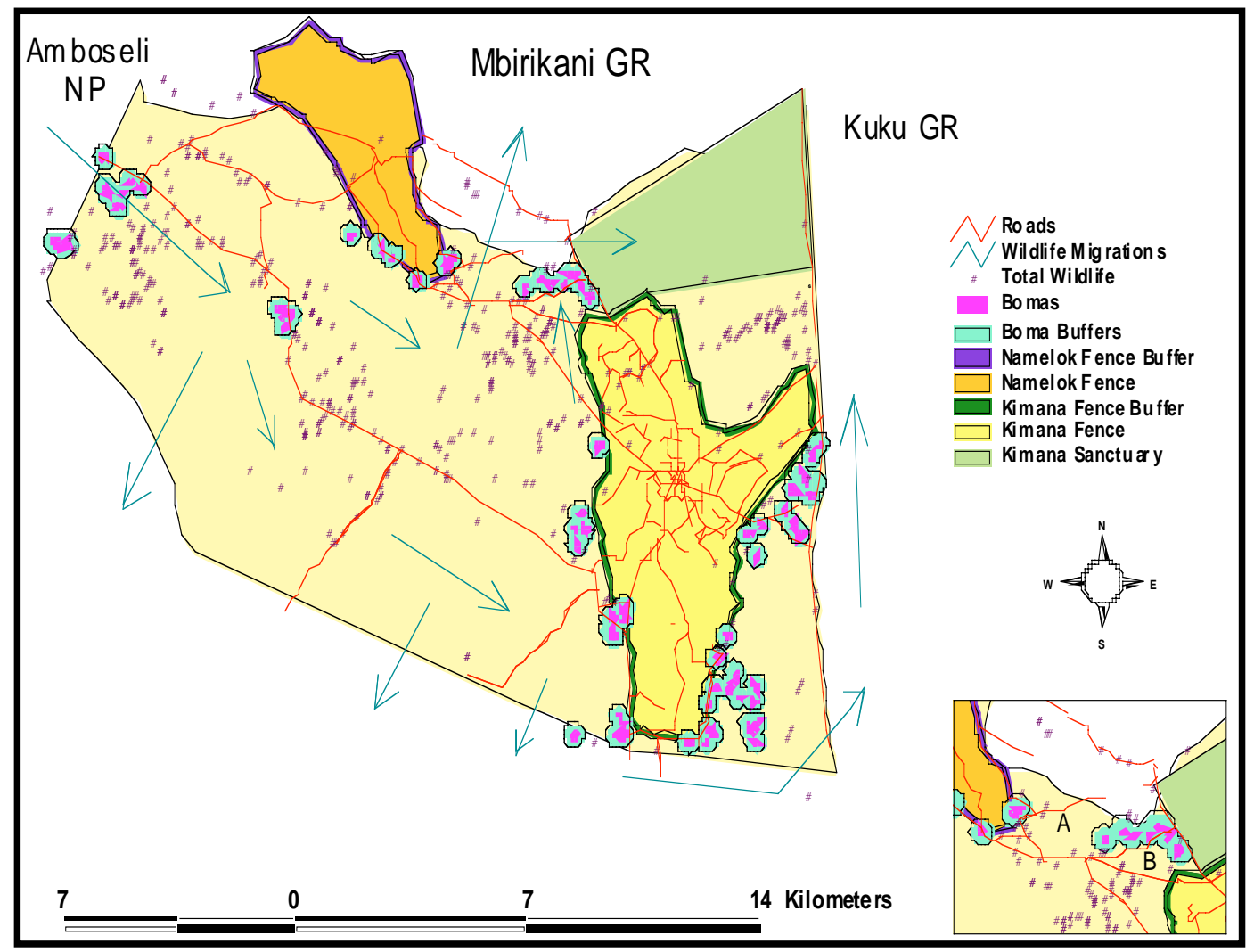

Fig. (3). Present potential migration routes of wildlife from Amboseli to KCWS. Inset: Remaining corridor for wildlife migration into KCWS $(\mathrm{A}=1.82 \mathrm{~km}, \mathrm{~B}=111.75 \mathrm{~m})$. The distance between the two fences into KCWS is about $5 \mathrm{~km}$.

are hired laborers and do not have enough money on which to live. Most engage is snaring mostly small and medium sized ungulates for easy bush meat.

The electric fences sealed in most permanent water sources (springs and rivers) with most of the water diverted for agriculture use upstream inside fences. Further, the fences were constructed longitudinally directly in the migration paths leading to the critical Kimana Swamp located in KCWS, hence cutting off critical dry season wildlife grazing area and access to water. These dual aspects have greatly compromised KGR as a viable dispersal area, and now more able to negatively affect economical and ecological viability of KCWS in the long term.

The Maasai bomas had a longer average displacement distance of wildlife. This distance was three times that of the electric fences. This large displacement effect partly arises 
from over-utilization of plant resources around bomas [16] that degrade and reduce wildlife habitat quality. Further, various activities associated with bomas such as livestock grazing, human presence, children playing noisily and even smoke emission from cooking also displace wildlife. This is also especially threatening to wildlife because the density of bomas will inevitably increase with the increasing human population. As more adults leave to establish new bomas to make room for new families, the number of bomas in the group ranch will inevitably increase, further displacing wildlife.

In a similar way, roads displaced wildlife because of their collective destruction of habitat in road network as well as noise and potential harm in accidental and deliberate deaths from vehicle and human traffic. Roads also have great fragmentation effect because of their relatively huge network that keep changing because of poor conditions. This degrades and destroys wildlife habitats and fragments the dispersal areas which may not be useful, even if available.

Livestock contribute to wildlife displacement through competition for resources and space. Sheep and goats were the cause of the most displacement of wildlife. This may be due to their large group size and feeding strategy; they compete with both wild grazers and browsers. Further, the seasonal migration patterns and foraging strategies of wildlife and livestock are similar such that their competition for pasture and water occurs throughout the year [17]. This suggests that there is direct competition for resources between wildlife and livestock, often leading to intense human - wildlife conflicts [18] displacement of wildlife, especially in the dry season when forage and water are scarce $[7,19]$.

Confining human structures / activities inside the electric fences may be a useful strategy to contain expansion of human settlements to one location where wildlife has already been displaced anyway. The problem with this is that it is not consistent with the Maasai's pastoral lifestyle, and the land inside the fence can not support all people, and has already been subdivided into individual ownership [20, 21]. However, most of the land outside the electric fence can still have defined land uses in a comprehensive integrated plan with neighboring wildlife protected areas that will incorporate people, livestock and wildlife. The challenge with this approach is lack of efficient and effective legal instruments and institutions for enforcement, especially in regards to environmental management.

The second option would be to have the remaining identified functional corridors, especially used by keystone and long raining species such as the elephant [22] and negotiate with blocks of land owners (where subdivision has already taken place) or group ranch leadership (where land is still under communal ownership) through a lease or compensation program [23] from a conservation fund established by stakeholders. Such land would be available for wildlife as priority, but may be used for pastoralism during droughts or long dry seasons.

The third option is to encourage landowners to pool together land (as seems to be now happening) and form communal and privately owned wildlife sanctuaries to tap into the lucrative tourism industry in the area. This would also bring direct benefits from conservation (through establishment of campsites or leasing to ecotourism investors, and money going to known landowners). Such land would also be used sustainably for pastoralism with owners' deliberately reducing livestock stocking density, and ensuring habitat quality and diversity for wildlife. Such private conservation areas would expand range and dispersal area for wildlife from the nearby protected areas as well as economic benefits [23], but will have to still be linked to each other by viable corridors and migration routes to avoid insularization.

In conclusion, similar work should be in other group ranches surrounding Amboseli National Park to establish both area and spatial orientation threats of human activities on wildlife movements. This will provide information for critical conservation action and monitoring purposes. Stakeholders and government should now urgently initiate conservation programs to address land use changes and potential impacts to wildlife dispersal in the area.

\section{ACKNOWLEDGEMENTS}

I would like to thank field assistants Salaash Koissaba, Paul Marias, John Mpaa, and John Karine for assisting with various research teams during data collection. I thank John Kioko, Dan Manina and Amanda Huelat who helped with spatial laying and analysis of different human structures and activities. I acknowledge the following members of November 2004 and April 2005 research teams: Jackie, Amis, Daniel Mannina, Meghan Massaua, Tessa Dawson, Bryce Bunker, Amanda Huelat, Kaira Wagoner, Siv Tang, Jeff Cherian, and Therese Tepe, Leann Wilkins, Robyn Carver, Lacey Doucet, Hance Ellington, Justine Ma, Megan McNaught, Miguel Ordenana, Margrett Reinert, and Benjamin Still. The School for Field Studies and its Kenyan Center for Wildlife Management Studies provided financial as well as logistical support for this work. I also thank the Kimana Group Ranch for showing interest in and supporting this research by allowing us access to its ranch. Anonymous reviewers improved earlier versions of this manuscript and I thank them.

\section{REFERENCES}

[1] Western D, Ssemakula J. The future of savannah ecosystem : ecological islands or faunal enclaves. Afr J Ecol 1981; 19: 7-19.

[2] Burkey TV. Faunal collapse in East African Game Reserves revisited. Biol Conserv 1995; 71: 107-10.

[3] Young TP, Mcclanahan TR, Eds. The East-African Ecosystems and their Conservation. New York: Oxford University Press 1996.

[4] Newmark WD. Insularization of Tanzanian parks and the local extinction of large mammals. Conserv Biol 1996; 10(6): 1549-56.

[5] Newmark WD. The role and designing of wildlife corridors and examples from Tanzania. Ambio 1993; 22: 500-4.

[6] Okello MM, Kiringe JW. Threats to biodiversity and their implications in protected and adjacent dispersal area of Kenya. J Sustainable Tourism 2004; 12(1): 55-69.

[7] Okello MM. Land use changes and human - wildlife conflicts in the Amboseli Area, Kenya. Hum Dimens Wildl 2005; 10(1): 19-28.

[8] Newmark WD. The conflicts between wildlife and local people living adjacent to protected areas in Tanzania: human density as a predictor. Conserv Biol 1994; 8(1): 249-55.

[9] Campbell DJ, Gichohi H, Mwangi A, Chege L. Land use conflict in Kajiado District, Kenya. Land Use Policy 2000; 17: 337-48.

[10] Sindiga I. Wildlife based tourism in Kenya: land use conflicts and government compensation polices over protected areas. J Tourism Stud 1995; 6(2): 45-55. 
[11] Lichtenfeld L. Local participation and conservation in kenya: a case study of the kimana community wildlife sanctuary. The $12^{\text {th }}$ Annual Meeting of the Society for Conservation Biology 1998.

[12] Western D. Amboseli national park: enlisting landowners to conserve migratory wildlife. Ambio 1982; 11(5): 302-8.

[13] Irigia BK. Kenya Wildlife Service. Environmental impact assessment of the proposed Kimana Wildlife Sanctuary. Community Wildlife Service, The Kenya Wildlife Service, KWS Nairobi, Kenya. 1995.

[14] Katampoi K, Genga G, Mwangi M, et al. Kajiado District Atlas. Asal Programme, Kajiado District Kajiado, Kenya. 1990.

[15] Mwale S. Changing relationships: the history and future of wildlife conservation in Kenya. Swara 2000; 22(4): 11-7.

[16] Kiringe JW, Okello MM. Use and availability of tree and shrub resources on Maasai communal rangelands near Amboseli, Kenya. Afr J Range Forage Sci 2005; 22(1): 37-46.

[17] Berger D. Wildlife Extension: Participatory conservation by the Maasai of Kenya. Acts Environmental Policy Series No. 4. Nairobi: Kenya 1993.

Received: September 04, 2008 Revised: March 17, 2009

Accepted: March 27, 2009
[18] Kenya Wildlife Service. Human wildlife conflicts in Kenya. Kenya Wildlife Service, Nairobi, Kenya 1994.

[19] Western D. Water availability and its influence on the structure and dynamics of a savannah large mammal community. East Afr Wildl J 1975; 13: 265-86.

[20] Pickard J. Recent trends and implications of group ranch subdivision and fragmentation in Kajiado District, Kenya. Geogr J 1998; 164(2): 202-8

[21] Galaty JG. This land is yours: social and economic factors in the privatization, subdivision and sale of Maasai ranches. Nomadic Peoples 1992; 30: 26-40.

[22] Western D. The ecological role of elephants in Africa. Pachyderm 1989; 12: 42-5.

[23] Ferraro PJ, Kiss A. Direct payments to conserve biodiversity. Science 2000; 298: 1718-9.

(C) Moses Makonjio Okello; Licensee Bentham Open.

This is an open access article licensed under the terms of the Creative Commons Attribution Non-Commercial License (http://creativecommons.org/licenses/by-nc/3.0/) which permits unrestricted, non-commercial use, distribution and reproduction in any medium, provided the work is properly cited. 